\title{
Adsorption of anionic dyes onto natural, thermally and chemically modified smectite clays
}

\author{
Joanna Kyzioł-Komosińska*, Czesława Rosik-Dulewska, Magdalena Pająk, Iwona Krzyżewska, \\ Agnieszka Dzieniszewska
}

Institute of Environmental Engineering of Polish Academy of Sciences, 34, M. Sklodowska-Curie Street, 41-819 Zabrze, Poland

"Corresponding author: e-mail: joanna.kyziol-komosinska@ipis.zabrze.pl

\begin{abstract}
The aim of this study was to determine the adsorption capacity of the smectite clays (from the overburden of the lignite deposit in Belchatow) for two anionic dyes, i.e. Reactive Blue 81 (RB-81) and Direct Blue 74 (DB-74). Additionally, the influence of the thermal and chemical (acid and alkali) clay modifications on the amount of bonded dyes was investigated. The adsorption capacity of the clay (natural and modified) was different for studied dyes and depended on the initial concentration and modification type. All the modified clays adsorbed the dyes at $\mathrm{pH}>\mathrm{pH}_{\mathrm{PZC}}$ as the negatively charged surfaces of their particles (in accordance with the formula: $\mathrm{AOH} \leftrightarrow \mathrm{AO}^{-}+$ $\mathrm{H}^{+}$) prevented the formation of electrostatic bonds between the anionic dyes and the clay surface. The dyes were mainly bound with the hydrogen bonds forming between the donor groups in the dyes and the acceptor groups $\left(-\mathrm{SiO}\right.$ and $\left.-\mathrm{Al}_{2} \mathrm{OH}\right)$ in the clays. The coefficients in the adsorption isotherms were estimated with the linear and non-linear regression. The linear regression method was found that the Freundlich and Dubinin-Radushkevich isotherms described the dye sorption much better than the Langmuir model. On the other hand, all three models described well the experimental data in the non-linear regression method. Furthermore, the $1 / \mathrm{n}$ value $(<1)$ obtained from the Freundlich equation for all the dye-sorbent systems indicated the favorable sorption.
\end{abstract}

Keywords: smectite clay, modified clay, Reactive Blue 81, Direct Blue 74, sorption isotherms, linear regression, non-linear regression.

\section{INTRODUCTION}

Dyes are one of the organic contaminants found in wastewater. They are generated by the paint, textile, cosmetic, paper and food industries ${ }^{1-3}$. At present, over 100.000 colors are used for commercial purposes. Their annual production is estimated at more than $7 \times 10^{5} \mathrm{Mg}$. $10-15 \%$ of dyes used in the coloring processes penetrate the water environment. They pose a threat because even low amounts of dyes cause water coloration and hinder the photosynthesis processes taking place in the aquatic organisms ${ }^{4}$. Dyes can also have a negative impact on the human health. They can cause skin and eye irritation. Some of them are toxic and carcinogenic ${ }^{5-7}$. In the textile industry, reactive, direct, acidic and alkaline dyes (whose character is cationic or anionic) are used to dye cellulose, protein and polyamide fibers.

The wastewater containing dyes should be treated before its discharge into water or sewerage systems. The adsorption techniques based on active carbons make effective methods of dye removal from water and wastewater at low and high concentrations ${ }^{8}$. However, the high cost of the activated carbon production and problems with its regeneration after the sorption capacity exhaustion make it necessary to look for more effective, easily accessible and economical sorption materials. Such materials can come both from natural and waste sources and need only simple preliminary preparation. These include zeolites, bentonite and bentonite clays, and smectite clays ${ }^{5,6,9,10-15}$. The smectite family minerals build clay rocks. They have high specific surface area and cation exchange capacity. Their layer structure indicates the possibility to increase these parameters due to thermal or chemical modifications.

Many studies demonstrate that smectite clays have a high sorption capacity for basic dyes ${ }^{15-17}$. However, there are very few works on the adsorption of anionic dyes. Large amounts of the anionic dyes are bound by the smectite clays at $\mathrm{pH}<2^{18}$. The sorption capacity also depends on the mineral composition of the clay, including the kaolinite content, i.e. Reactive Blue 81 and Direct Blue 74. It was also conducted to determine the effects of thermal and chemical modifications of the clay on its sorption capacity. The estimated sorption parameters helped to determine the bonding mechanism in the investigated dyes.

\section{MATERIAL AND EXPERIMENTAL METHODS}

\section{Clay sorbents}

The smectite clay from the Belchatow deposit of the lignite mine "Belchatow" was used in the study. It was dried at room temperature $\left(25 \pm 2^{\circ} \mathrm{C}\right)$ and crushed to a fraction $(<0.5 \mathrm{~mm})$. The investigations also embraced the clay forms after modifications. They included the thermal modification (heating at $250^{\circ} \mathrm{C}$ ); the acidic one (with $16 \% \mathrm{H}_{2} \mathrm{SO}_{4}$ solution at $96^{\circ} \mathrm{C}$ for 8 hours, the ratio of the solid phase to solution $=1: 5)^{21}$; and alkaline one (with $5 \mathrm{M} \mathrm{NaOH}$ solution at $90^{\circ} \mathrm{C}$, the ratio of the solid phase to solution $=1: 5)^{22}$.

Typical methods applied in the mineralogical research were used to determine the characteristics of the natural and modified clay samples ${ }^{23}$. These encompassed mineral and chemical compositions, major functional groups and physicochemical properties (total $\left(\mathrm{SSA}_{2} \mathrm{O}\right)$ and external $\left(\mathrm{SSA} \mathrm{N}_{2}\right.$ ) specific surface area, porosity (n), an average pore diameter (d), cation exchange capacity (CEC) and the exchangeable cations). Moreover, $\mathrm{pH}$ values and the isoelectric point $\left(\mathrm{pH}_{\mathrm{PZC}}\right)$, defined by the $\mathrm{pH}$ in which the 
a)

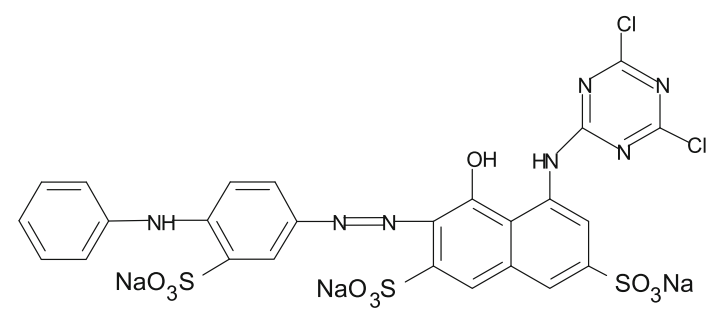

b)

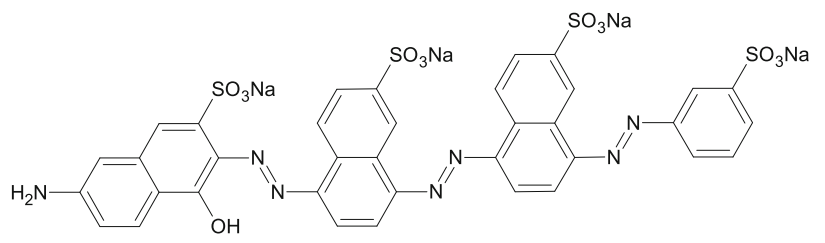

Figure 1. Structural formulas of the RB-81 (a) and DB-74 (b) dyes

charge of the colloidal particles is equal to zero, were also determined (Table 1).

\section{Dyes}

Two anionic water-soluble dyes (Boruta-Zachem Kolor Ltd.) were used in the laboratory tests:

- a reactive dye: Reactive Blue 81 (RB-81) - C.I. 18245, CAS 75030-18-1, $\mathrm{C}_{25} \mathrm{H}_{14} \mathrm{Cl}_{2} \mathrm{~N}_{7} \mathrm{O}_{10} \mathrm{~S}_{3} \cdot 3 \mathrm{Na}, \mathrm{M} 808 \mathrm{~g} \cdot \mathrm{mol}^{-1}$, $\mathrm{pH}$ of the $1-\mathrm{g} \cdot \mathrm{dm}^{-3}$ dye solution concentration $=4.97$;

- a direct dye: Direct Blue 74 (DB-74) - C.I. 34146, CAS 33540-94-2, C $36-\mathrm{H}_{21}-\mathrm{N}_{7}-\mathrm{O}_{13}-\mathrm{S}_{4} \cdot 4 \mathrm{Na}, \mathrm{M} 979,8$ $\mathrm{g} \cdot \mathrm{mol}^{-1}, \mathrm{pH}$ of the $1-\mathrm{g} \cdot \mathrm{dm}^{-3}$ dye solution concentration $=8.03$.

The structural formulas of the tested dyes are shown in Figure 1.

\section{Experimental method}

The sorption capacities of the natural and modified clays for the RB-81 and DB-74 dyes were determined with the batch method under static conditions contacting the solid phase : the dye solution. Aqueous dye solutions (initial concentrations of 1, 10, 25, 50, 100, 150, 250, 500,750 , and $1000 \mathrm{mg} \cdot \mathrm{dm}^{-3}$ ) obtained though diluting the stock solution with distilled water $\left(1000 \mathrm{mg} \cdot \mathrm{dm}^{-3}\right)$. The solid phase-solution ratio was 1:20 (i.e. $1 \mathrm{~g}$ of the clay sample $+20 \mathrm{ml}$ of dye solution at the adequate concentration level). The shaking time was 24 hours. Then, the solution was separated from the solid phase during 20-minute centrifugation (4000 rpm).

The concentrations of the RB-81 and DB-74 dyes in the initial $\left(\mathrm{C}_{0}\right)$ and equilibrium $\left(\mathrm{C}_{\mathrm{eq}}\right)$ solutions were determined with the UV-Vis spectrometry (Varian Cary 50 Scan UV-VIS spectrometer) at wavelengths of 584 $\mathrm{nm}$ and $582 \mathrm{~nm}$, respectively. Moreover, the $\mathrm{pH}$ values were measured in all the equilibrium solutions.

The dye amount $(\mathrm{q})$ adsorbed onto the clay phase and the percentage removal of dye from solution $(\mathrm{R})$ were calculated from the following formulas:

$\mathrm{q}=\left(\mathrm{C}_{0}-\mathrm{C}_{\mathrm{eq}}\right) \frac{\mathrm{V}}{\mathrm{m}}\left(\mathrm{mg} \cdot \mathrm{kg}^{-1}\right)$

$\mathrm{R}=\frac{\mathrm{C}_{0}-\mathrm{C}_{\mathrm{eq}}}{\mathrm{C}_{0}} \cdot 100 \%$

where:

$\mathrm{q}$ - the amount of the dye adsorbed by the clay particles $\left(\mathrm{mg} \cdot \mathrm{kg}^{-1}\right)$, $(\%)$,

$\mathrm{C}_{0}$ - the initial concentration of the dye solution $\left(\mathrm{mg} \cdot \mathrm{dm}^{-3}\right)$,

$\mathrm{C}_{\mathrm{eq}}$ - the equilibrium concentration of the dye solution $\left(\mathrm{mg} \cdot \mathrm{dm}^{-3}\right)$, $\mathrm{m}$ - the sorbent mass $(\mathrm{kg})$,

$\mathrm{V}$ - the solution volume $\left(\mathrm{dm}^{3}\right)$.

The obtained results allowed the determination of the sorption isotherms in the system of $q=f\left(C_{e q}\right)$ and dye removal curves in the system of $R=f\left(C_{0}\right)$.

\section{Estimating the sorption parameters}

To interpret the experimental data on the sorption of dyes onto clay particles, three non-linear isotherms ${ }^{25-27}$ were used:

- the Freundlich adsorption isotherm:

$\mathrm{q}=\mathrm{K}_{\mathrm{F}} \mathrm{C}_{\mathrm{eq}}^{1 / \mathrm{n}}$

- the Langmuir adsorption isotherm:

$\mathrm{q}=\frac{\mathrm{q}_{\mathrm{L}} \mathrm{K}_{\mathrm{L}} \mathrm{C}_{\mathrm{eq}}}{1+\mathrm{K}_{\mathrm{L}} \mathrm{C}_{\mathrm{eq}}}$

- the Dubinin-Radushkevich adsorption isotherm:

$\mathrm{q}=\mathrm{q}_{\mathrm{D}} \cdot \exp \left(-\beta \varepsilon^{2}\right)$

The parameters in the equations (3-5) were estimated with the linear and non-linear regression methods.

The linear regression method was based on the transformation of the equation to the linear form of the following formulas:

- the Freundlich isotherm:

$\log (\mathrm{q})=\log \left(\mathrm{K}_{\mathrm{F}}\right)+\frac{1}{\mathrm{n}} \log \left(\mathrm{C}_{\mathrm{eq}}\right)$

where:

$\mathrm{K}_{\mathrm{F}}$ - the sorption capacity coefficient $\left(\mathrm{dm}^{3} \cdot \mathrm{kg}^{-1}\right)$,

$1 / \mathrm{n}$ - the heterogeneity parameter, the closer the $1 / \mathrm{n}$ value to zero is, the more heterogeneous ${ }^{28}$ the surface becomes. Moreover, the $1 / \mathrm{n}$ value determines the adsorption intensity.

- the Langmuir isotherm:

$\frac{\mathrm{C}_{\mathrm{eq}}}{\mathrm{q}}=\frac{1}{\mathrm{q}_{\mathrm{L}}} \mathrm{C}_{\mathrm{eq}}+\frac{1}{\mathrm{~K}_{\mathrm{L}} \mathrm{q}_{\mathrm{L}}}$

where:

$\mathrm{q}_{\mathrm{L}}$ - the maximum adsorption capacity of the sorbent for a dye $\left(\mathrm{mg} \cdot \mathrm{kg}^{-1}\right)$,

$\mathrm{K}_{\mathrm{L}}$ - the adsorption equilibrium constant $\left(\mathrm{dm}^{3} \cdot \mathrm{mg}^{-1}\right)$.

- the Dubinin-Radushkevich isotherm:

$\ln (\mathrm{q})=\ln \left(\mathrm{q}_{\mathrm{D}}\right)-\beta \varepsilon^{2}$

where:

$\mathrm{q}_{\mathrm{D}}$ - the sorption capacity $\left(\mathrm{mol} \cdot \mathrm{kg}^{-1}\right)$,

$\beta$ - the constant $\left(\mathrm{mol}^{2} \cdot \mathrm{J}^{-2}\right)$,

$\varepsilon$ - the Polanyi potential $\left(\mathrm{J} \cdot \mathrm{mol}^{-1}\right)$ is equal to

$\varepsilon=\mathrm{RT} \ln \left(1+\frac{1}{\mathrm{C}_{\mathrm{eq}}}\right)$

where: $\mathrm{R}$ - the gas constant $\left(8.314 \mathrm{~J} \cdot \mathrm{mol}^{-1} \mathrm{~K}^{-1}\right), \mathrm{T}-$ absolute temperature (K). 
The values of the $1 / \mathrm{n}$ and $\mathrm{K}_{\mathrm{F}}$ parameters in Eq. (6) were estimated by plotting $\log (\mathrm{q})$ vs $\log \left(\mathrm{C}_{\mathrm{eq}}\right)\left(\mathrm{K}_{\mathrm{F}}=\right.$ $\exp ($ intercept $), 1 / n=$ slope $)$. The values of $\mathrm{q}_{\mathrm{L}}$ and $\mathrm{K}_{\mathrm{L}}$

in Eq. (7) were calculated from the dependence $\frac{\mathrm{C}_{\text {eq }}}{q}$

vs $\mathrm{C}_{\mathrm{eq}}\left(\mathrm{q}_{\mathrm{L}}=1 /\right.$ slope, $\mathrm{K}_{\mathrm{L}}=1 /\left(\right.$ intercept $\left.\times \mathrm{q}_{\mathrm{L}}\right)$. Finally, the parameters $\mathrm{q}_{\mathrm{D}}$ and $\beta$ in Eq. (8) were computed from the correlation: $\ln (\mathrm{q}) v s \varepsilon^{2}\left(\mathrm{q}_{\mathrm{D}}=\exp (\right.$ intercept $)$, $\beta=-$ (slope).

The computer software Statistica (ver. 9.0) was used to estimate the values of coefficients in the sorption equations with the non-linear regression method. It is based on the method of least squares method with the Gauss-Newton estimation algorithm.

The value of the adsorption equilibrium constant $\mathrm{K}_{\mathrm{L}}$ estimated from Eq. (7), allowed the calculation of the separation factor $\mathrm{R}_{\mathrm{L}}$ from the equation:

$\mathrm{R}_{\mathrm{L}}=\frac{1}{1+\mathrm{K}_{\mathrm{L}} \cdot \mathrm{C}_{0}}$

where:

$\mathrm{C}_{0}$ - the highest initial dye concentration in the experimental solution $\left(\mathrm{mg} \cdot \mathrm{dm}^{-3}\right)$.

The value of $\beta$ constant was estimated from Eq. (8). It was used to determine free energy $\mathrm{E}$ per dye molecule from the equation:

$\mathrm{E}=\frac{1}{(2 \beta)^{1 / 2}}\left(\mathrm{~kJ} \cdot \mathrm{mol}^{-1}\right)$

Using the estimated values of the $1 / n, R_{L}$ and $E$ parameters, the researchers attempted to determine the mechanism of the dye bonding onto the clay particles and adsorption conditions.

The value of the $1 / \mathrm{n}$ parameter $<1$ (Eq. 6) indicated a favorable sorption process ${ }^{\mathbf{2 8}, 29}$. The value of the $\mathrm{R}_{\mathrm{L}}$ (Eq. 10) parameter indicated the following adsorption conditions: when $\mathrm{R}_{\mathrm{L}}>1$ - adsorption conditions were unfavorable; $\mathrm{R}_{\mathrm{L}}=1$ - linear adsorption, $0<\mathrm{R}_{\mathrm{L}}<1$ - adsorption conditions were favorable; and when $\mathrm{R}_{\mathrm{L}}=0$ - irreversible adsorption. The value of the free energy per one dye molecule (E) estimated from Eq. (11) allows differentiation of the physical adsorption $(\mathrm{E}<8$ $\left.\mathrm{kJ} \cdot \mathrm{mol}^{-1}\right)$ from the ion exchange $\left(8<\mathrm{E}<16 \mathrm{~kJ}^{\prime} \mathrm{mol}^{-1}\right)$. However, the $\mathrm{q}_{\mathrm{L}}$ parameter estimated from the Eq. (7) indicated the monolayer capacity, i.e. the maximum sorption capacity of clay for the dye.

\section{RESULTS AND DISCUSSION}

\section{Physicochemical properties of the natural and thermally} and chemically modified clays

The mineral components of clay from the Belchatow deposit included Ca-smectite and kaolinite, which belong to clay minerals, and quartz and calcite, which are non-clay minerals ${ }^{23}$. Its chemical and mineral compositions were related. The clay contained $\mathrm{SiO}_{2}(55.81 \%), \mathrm{Al}_{2} \mathrm{O}_{3}$ (15.25\%), $\mathrm{Fe}_{2} \mathrm{O}_{3}(6.45 \%), \mathrm{CaO}(2.82 \%), \mathrm{MgO}(1.4 \%)$, $\mathrm{Na}_{2} \mathrm{O}(0.42 \%), \mathrm{K}_{2} \mathrm{O}(0.7 \%)$. The $\mathrm{SiO}_{2} / \mathrm{Al}_{2} \mathrm{O}_{3}$ ratio was 3.66 .

The infrared spectra of clays demonstrated that the main surface functional groups were:
- dissociated silanol groups (-Si-O) in the tetrahedral sheets (bands at $1054 \mathrm{~cm}^{-1}$ and $474 \mathrm{~cm}^{-1}$ ),

- aluminol groups $\left(-\mathrm{Al}_{2}-\mathrm{OH}\right)$ in the octahedral sheets (band at $921 \mathrm{~cm}^{-1}$ ),

- $-\mathrm{AlFe}-\mathrm{OH}$ groups, reflecting the partial substitution of the octahedral Al by Fe (band at $873 \mathrm{~cm}^{-1}$ ),

- $\mathrm{OH}$ groups, originating from the smectite and kaolinite minerals (band at $3623 \mathrm{~cm}^{-1}$ ),

- -H-O-H molecules of water adsorbed in the smectite minerals (bands at $3430 \mathrm{~cm}^{-1}$ and $1654 \mathrm{~cm}^{-1}$ ) 23 (Fig. 2).

The groups were responsible for the surface charge of the particles. They could act as both donors and acceptors of protons in a hydrogen bond.

Moreover, the doublet at 802 and $800 \mathrm{~cm}^{-1}$ and $1448 \mathrm{~cm}^{-1}$ bands pointed to the presence of quartz and calcite admixtures, respectively.

The cation exchange capacity (CEC) of the clay was $82.39 \mathrm{cmol}_{+} \cdot \mathrm{kg}^{-1}$. The main exchangeable cations were $\mathrm{Ca}^{2+}$ and $\mathrm{Mg}^{2+11}$. The external and total specific surface areas were $41.38 \mathrm{~m}^{2} \cdot \mathrm{g}^{-1}$ and $141.83 \mathrm{~m}^{2} \cdot \mathrm{g}^{-1}$, respectively. The porosity was 0.0682 .

During the clay drying at $250^{\circ} \mathrm{C}$, two phenomena occurred, i.e. the dehydration (removal of water molecules) of the smectite mineral and decrease in the peak intensity at $3430 \mathrm{~cm}^{-1}$ and $1654 \mathrm{~cm}^{-1}$ bands, which caused the increase in the porosity value $(0.1113)$ and the pore diameter $(0.0322 \mu \mathrm{m})$. There was also a nearly two-fold increase in the external surface area (Table 1).

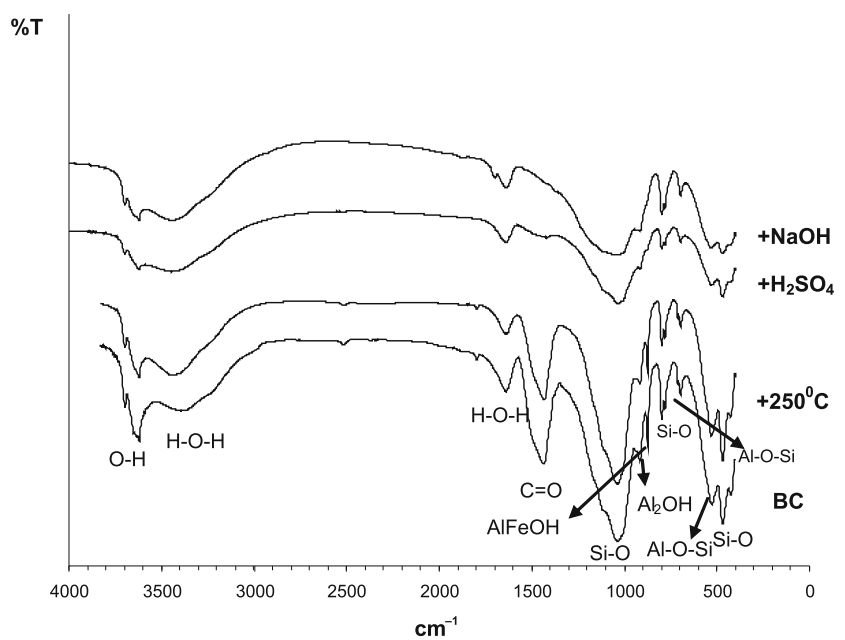

Figure 2. FTIR spectra of the smectite clay (BC) - natural clay; thermally and chemically modified clay

The clay particles were treated with a $16 \%$ solution of $\mathrm{H}_{2} \mathrm{SO}_{4}$. As a result, the octahedral smectite sheets were destroyed, which was confirmed by the complete disappearance of the peak intensity of the characteristic band at $873 \mathrm{~cm}^{-1}$ and the decrease in the intensity at $921 \mathrm{~cm}^{-1}$ and $536 \mathrm{~cm}^{-1}$. There was also a decrease in the vibration intensity at $1054 \mathrm{~cm}^{-1}$ and $474 \mathrm{~cm}^{-1}$ related to the degradation of the tetrahedral sheets. Calcite was dissolved (according to the reaction: $\mathrm{CaCO}_{3}+\mathrm{H}_{2} \mathrm{SO}_{4} \rightarrow$ $\left.\mathrm{Ca}^{2+}+\mathrm{SO}^{2+}{ }_{4}+\mathrm{CO}_{2}+\mathrm{H}_{2} \mathrm{O}\right)$, which was demonstrated by the disappearance of the intensity of a band at 1448 $\mathrm{cm}^{-1}$. The exchange of the used $\mathrm{H}_{2} \mathrm{SO}_{4}$ during the clay modification was performed in accordance with the methodology and prevented the $\mathrm{CaSO}_{4}$ precipitation ${ }^{21}$. Due to the octahedral sheets destruction, the percentage of the silica in the samples rose and the value of 
the calculated $\mathrm{SiO}_{2} / \mathrm{Al}_{2} \mathrm{O}_{3}$ ratio increased to 17.25 . The acid modification of clay induced a six-fold porosity growth $(0.4268)$, whereas the average pore diameter increased to $2.1068 \mu \mathrm{m}$. Moreover, the external specific surface area rose twice $\left(77.44 \mathrm{~m}^{2} \cdot \mathrm{g}^{-1}\right)$. The saturation of the sorption complex with the $\mathrm{H}^{+}$ions resulted in the reductions of the $\mathrm{pH}$ (3.39) and $\mathrm{CEC}$ value $(78.55$ $\mathrm{cmol}_{+} \cdot \mathrm{kg}^{-1}$ ) (Table 1 ).

The studied clay was also modified with the $5 \mathrm{M} \mathrm{NaOH}$ solution. The process brought about the decrease in the intensity of the bands at $1054 \mathrm{~cm}^{-1}$ and $476 \mathrm{~cm}^{-1}$, which came from the -Si-O group vibrations, and was related to the destruction of the smectite tetrahedral sheets. Additionally, the peak of a band at $1448 \mathrm{~cm}^{-1}$, derived from the dissolved calcite (according to reaction: $\mathrm{CaCO}_{3}$ $+\mathrm{NaOH} \rightarrow \mathrm{Na}_{2} \mathrm{CO}_{3}+\mathrm{CaO}+\mathrm{H}_{2} \mathrm{O}$ ), disappeared. As the tetrahedral sheets were destroyed, the $\mathrm{SiO}_{2} / \mathrm{Al}_{2} \mathrm{O}_{3}$ ratio lowered to 0.82 .

The alkaline clay modification induced the eight-fold increase in the porosity $(0.5334)$. The average pore diameter rose to $0.6362 \mu \mathrm{m}$, whereas the total and external surface areas increased to $214 \mathrm{~m}^{2} \cdot \mathrm{g}^{-1}$ and $50.09 \mathrm{~m}^{2} \cdot \mathrm{g}^{-1}$, respectively. The saturation of the sorption complex with $\mathrm{Na}^{+}$ions and the increase in the CEC value (96.57 $\mathrm{cmol}_{+} \cdot \mathrm{kg}^{-1}$ ) were also observed (Table 1 ).
The variation in the CEC value correlated with the changes in the total specific surface area of the samples ${ }^{\mathbf{3 0}}$.

The sorption of the reactive $\mathrm{RB}-81$ and direct $\mathrm{DB}-74$ dyes onto the natural and modified clay particles

The experimental adsorption isotherms of the RB-81 and DB-74 dyes onto smectite clays (natural, thermally and chemically modified clays) are presented in the system of $\mathrm{q}=\mathrm{f}\left(\mathrm{C}_{\mathrm{eq}}\right)$ (Fig. 3). The dye removal curves from the solution are given in the system of $\mathrm{R}=\mathrm{f}\left(\mathrm{C}_{0}\right)$ (Fig. 4). The results of the $\mathrm{pH}$ measurements in the equilibrium solutions after sorption are shown in Figure 5.

When the adsorbed amount of the studied dyes was analyzed (depending on their initial concentrations in the solution), it was found that the clay with the natural sorption complex adsorbed $18.8-2870 \mathrm{mg} \cdot \mathrm{kg}^{-1}$ of the RB-81 dye. This indicated the dye removal from the solution at the level of 94-14.15\%. On the other hand, the sorption capacity of the clay for the DB-74 dye was larger and ranged between $19.2 \mathrm{mg} \cdot \mathrm{kg}^{-1}$ and 4700 $\mathrm{mg} \cdot \mathrm{kg}^{-1}$. The dye percentage removal from the solution was between 96 and $22.66 \%$.

Even though the RB-81 $\mathrm{pH}$ was acidic (4.97) and the DB-74 was alkaline (8.03), the correlation curves of the $\mathrm{pH}$ values and the dye concentration in the equilibrium solution indicated that the sorption process of the te-

Table 1. Physicochemical properties of smectite clay: natural one $(\mathrm{BC})$ and modified thermally $(\mathrm{BC} 250)$, with acid $\left(\mathrm{BC}_{2} \mathrm{SO}_{4}\right)$ and alkali $(\mathrm{BC} \mathrm{NaOH})$

\begin{tabular}{|c|c|c|c|c|c|c|c|c|}
\hline & \multicolumn{2}{|c|}{$\begin{array}{c}\text { SSA } \\
{\left[\mathrm{m}^{2} \cdot \mathrm{g}^{-1}\right]}\end{array}$} & \multirow[t]{2}{*}{$\mathrm{n}$} & \multirow[t]{2}{*}{$d[\mu m]$} & \multirow{2}{*}{$\mathrm{SiO}_{2} / \mathrm{Al}_{2} \mathrm{O}_{3}$} & \multirow{2}{*}{$\begin{array}{c}\text { CEC } \\
{\left[\mathrm{cmol}_{+} \mathrm{kg}^{-1}\right]}\end{array}$} & \multirow[t]{2}{*}{$\mathrm{pH}_{\mathrm{H} 2 \mathrm{O}}$} & \multirow[t]{2}{*}{$\mathrm{pH}_{\mathrm{PZC}}$} \\
\hline & $\mathrm{H}_{2} \mathrm{O}$ & $\mathrm{N}_{2}$ & & & & & & \\
\hline $\mathrm{BC}$ & 141.83 & 41.38 & 0.0682 & 0.0186 & 3.66 & 82.39 & 7.85 & 7.42 \\
\hline BC 250 & 150.20 & 70.94 & 0.1113 & 0.0322 & 3.42 & 80.40 & 7.83 & 7.20 \\
\hline $\mathrm{BC} \mathrm{H}_{2} \mathrm{SO}_{4}$ & 143.21 & 77.44 & 0.4268 & 2.1068 & 17.25 & 78.55 & 3.39 & 3.22 \\
\hline $\mathrm{BC} \mathrm{NaOH}$ & 214.09 & 50.09 & 0.5334 & 0.6362 & 0.82 & 96.57 & 10.28 & 9.66 \\
\hline
\end{tabular}
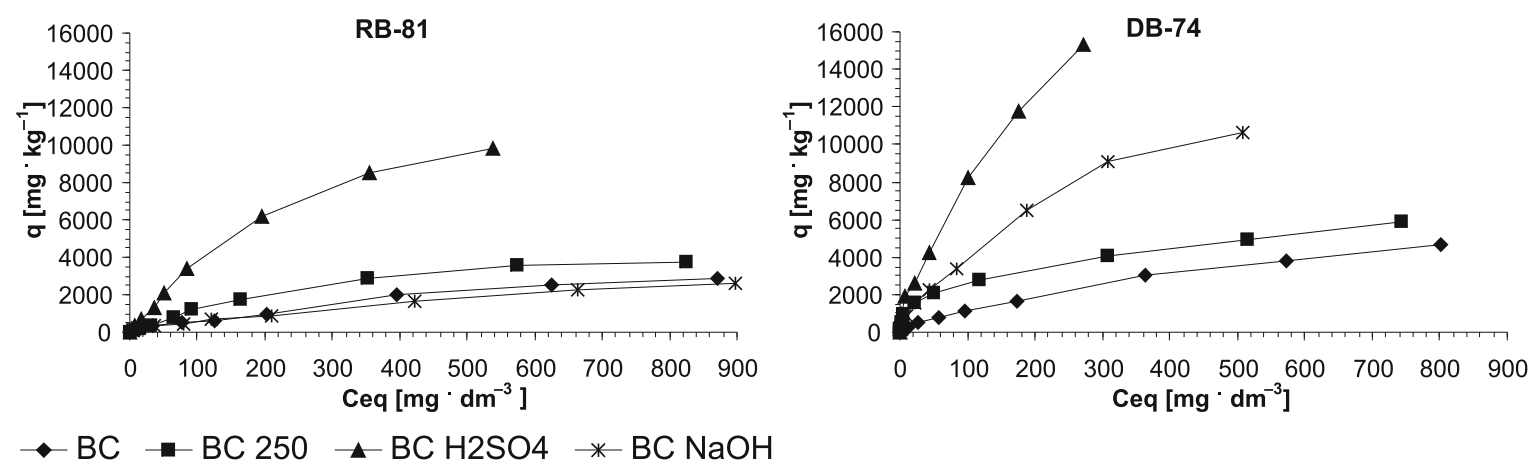

Figure 3. Experimental sorption isotherms of the RB- 81 and DB-74 dyes onto smectite clays: natural ones (BC) and modified thermally (BC 250), with acid $\left(\mathrm{BC}_{2} \mathrm{SO}_{4}\right)$ and alkali $(\mathrm{BC} \mathrm{NaOH})$
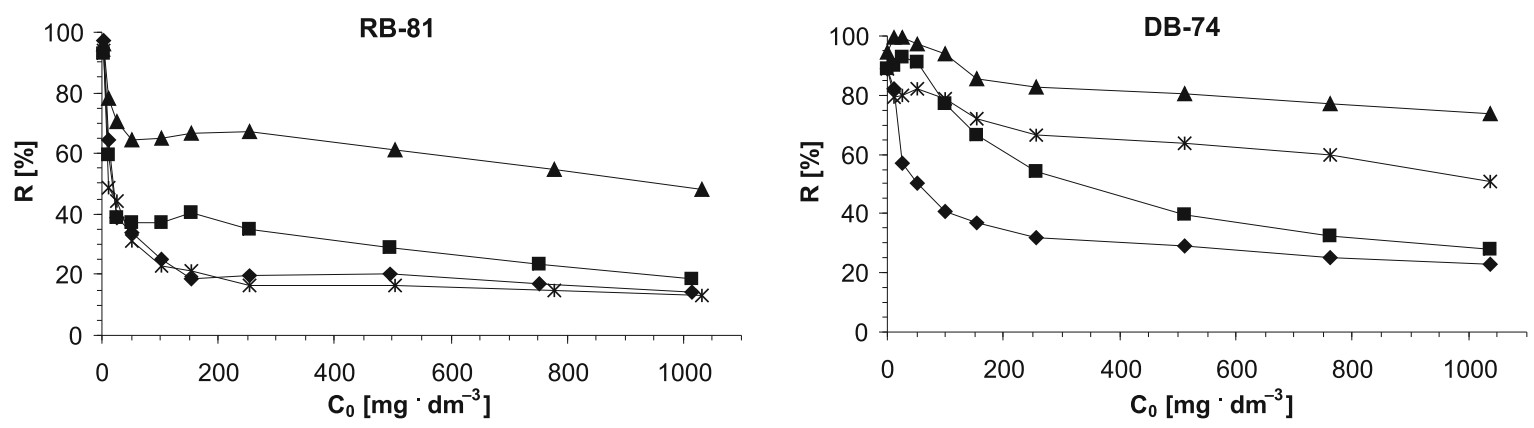

$\mathrm{BC}-\mathrm{BC} 250 \rightarrow \mathrm{BC} \mathrm{H} 2 \mathrm{SO} 4 \rightarrow \mathrm{BC} \mathrm{NaOH}$

Figure 4. The percentage removal of the RB- 81 and DB-74 dyes using natural $(\mathrm{BC})$ and thermally $\left(\mathrm{BC}_{250)}\right.$, acid $\left(\mathrm{BC}_{2} \mathrm{H}_{2}\right)$ and alkali $(\mathrm{BC} \mathrm{NaOH})$ modified smectite clays 

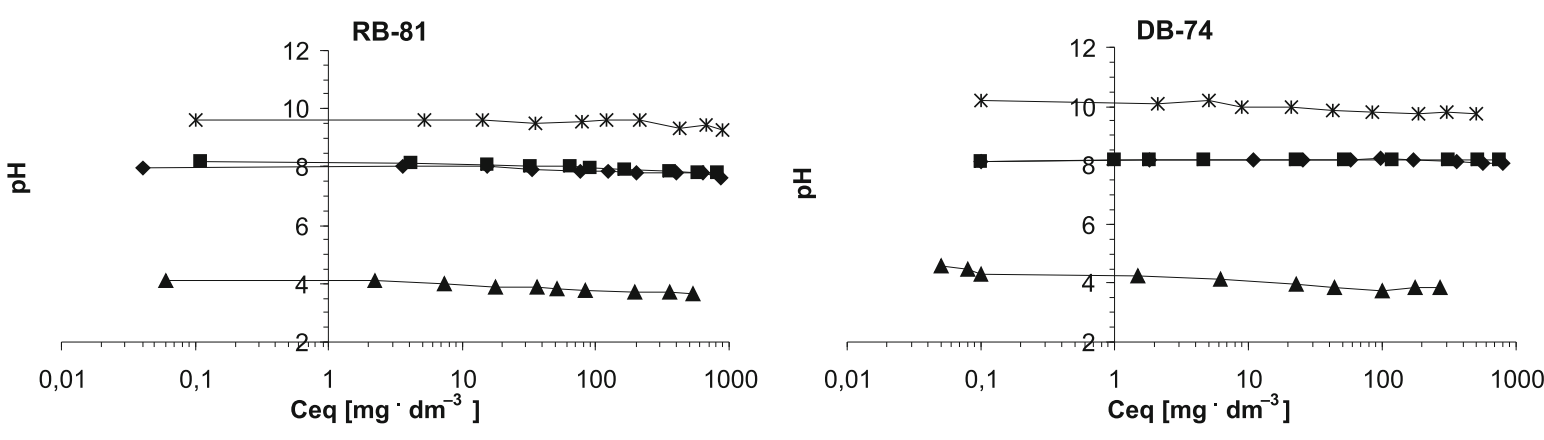

$-\mathrm{BC}-\mathrm{BC} 250 \_\mathrm{BC} \mathrm{H} 2 \mathrm{SO} 4 * \mathrm{BC} \mathrm{NaOH}$

Figure 5. The $\mathrm{pH}$ values in the equilibrium solutions of the RB-81 and DB-74 dyes

sted dyes proceeded at practically constant $\mathrm{pH}$ values (7.65-8.09) (Fig. 5). Such a situation was caused by the good buffer properties of the smectite clay. When comparing the $\mathrm{pH}$ values in the equilibrium solutions with the isoelectric point value of the clay $\left(\mathrm{pH}_{\mathrm{PZC}}\right)$, it was found that the $\mathrm{pH}$ value in the equilibrium solution was higher than the clay $\mathrm{pH}_{\mathrm{PZC}}$. Under these conditions, the surface charge of the smectite clay was negative according to the reaction: $\mathrm{AOH} \leftrightarrow \mathrm{AO}^{-}+\mathrm{H}^{+}$(where $\mathrm{A}-\mathrm{Si}$ or $\mathrm{Al})$.

The findings demonstrate that the studied anionic dyes could not be bound onto mineral surfaces due to the electrostatic interactions. The dye structures, in which the proton donor groups were present (e.g. -OH hydroxyl and $-\mathrm{NH}$ and- $\mathrm{NH}_{2}$ amino groups), lead to a conclusion that the dyes could be bound with smectite clay through a hydrogen bond. In such a case, the dissociated silanol (-Si-O) and aluminol (-Al-OH) groups acted as the acceptors. Furthermore, the interlayer $\mathrm{Ca}^{2+}$ ions hydrated by water molecules occurred in the smectite structure. The dissociation degree of those water molecules was approx. $10^{7}$ times higher than the liquid water dissociation degree. The discussed water molecules could be the donor of protons in the hydrogen bonds with the dye sulfonate groups acting as the acceptors. In the RB- 81 and DB-74 structures, there were three and four sulfonate groups, respectively. The hydrated interlayer $\mathrm{Ca}^{2+}$ ions could participate in the dye bonding because of the reaction with the sulfonic anion $-\mathrm{SO}_{3}{ }^{-}$(according to the formula: $\left.\mathrm{Ca}\left(\mathrm{H}_{2} \mathrm{O}\right)_{6}{ }^{2+} \leftrightarrow-\mathrm{SO}_{3}{ }^{-}\right)^{19}$. However, this process was limited due to the large size of the dye particles.

Heating the clay at $250^{\circ} \mathrm{C}$ brought about the increase in its sorption capacity for both dyes in the whole range of the initial concentrations (Fig. 4). The maximum sorption capacities of the clay for the RB-81 and DB-74 dyes increased by $31.22 \%\left(3766 \mathrm{mg} \cdot \mathrm{kg}^{-1}\right)$ and $24.42 \%$ $\left(5848 \mathrm{mg} \cdot \mathrm{kg}^{-1}\right)$, respectively (Fig. 3). The dyes removal depended on their concentrations in the solution. For the RB- 81 it was from $95 \%$ to $18.56 \%$, and for the DB-74 it was from $98 \%$ to $28.2 \%$ (Fig. 4). The sorption processes of both dyes onto the thermally modified clay proceeded at the $\mathrm{pH}$ values similar to the natural clay $\mathrm{pH}$. The increase in the sorption capacity of the thermally modified clay for both dyes resulted mainly from the increase in its external surface and porosity (Table 1).

The acid activation of the clay caused a significant increase in the sorption capacity for both dyes in the whole concentration range. When the initial dye concentration was $1000 \mathrm{mg} \cdot \mathrm{dm}^{-3}$, the amounts of the bound RB-81 and DB-74 dyes were $9860 \mathrm{mg} \cdot \mathrm{kg}^{-1}$ and $15324 \mathrm{mg} \cdot \mathrm{kg}^{-1}$, respectively (Fig. 3). This indicates the increase in the sorption capacity of the acid-modified clay by $244 \%$ and $226 \%$, respectively. The calculated percentage removal of the RB-81 and DB-74 dyes from the solution was $96-47.87 \%$ and $98-73.89 \%$, respectively. Both dyes were bound in an acid medium at the $\mathrm{pH}$ of 4.56-3.62. When taking into account the $\mathrm{pH}_{\mathrm{PZC}}$ value of the acid-modified clay (3.22), the charge of surface particle was negative during the sorption. Moreover, the dyes were mainly bonded by the hydrogen bonds. The acid modification of the clay resulted in the increases in its external surface, porosity and diameter of the pores that facilitated the access of the dye ions to the surface functional groups. On the other hand, the interlayer cations of the natural smectite clay were replaced with protons in the form of hydronium ions $\left(\mathrm{H}_{3} \mathrm{O}^{+}\right)$. Consequently, this caused increases in both the Brønsted-type acid centers and sorption capacities.

Due to the treatment of clay samples with the $5 \mathrm{M}$ $\mathrm{NaOH}$ solution, the clay sorption capacity increased by $125 \%$ (when compared to the natural clay) for the DB-74 dye and reached its maximum level of $10600 \mathrm{mg} \cdot \mathrm{kg}^{-1}$. The percentage removal of the DB-74 dye was 94-51.11\%. The amounts of the bonded RB-81 dye were lower $\left(17.5-2652 \mathrm{mg} \cdot \mathrm{kg}^{-1}\right)$.

The dye sorption processes occurred at the alkaline solution $\mathrm{pH}$ (9.75-10.22), which was lower than the clay $\mathrm{pH}_{\mathrm{PZC}}$. Due to the alkaline modification, the tetrahedral sheets of the smectite mineral were destructed and the number of the Si-O groups was considerably reduced. What is more, the access of the dyes to the aluminol groups improved, and the sorption complex was saturated with the $\mathrm{Na}^{+}$ions. When compared with the natural clay, the porosity and total and external surface areas increased. The presence of the $\mathrm{Na}^{+}$ions in the interlayer structures (their ability for the water molecule polarization is lower than that of $\mathrm{Ca}^{2+}$ ions) was one of the reasons for the lower sorption capacity of the alkali-modified clays.

Importantly, the lower adsorption of acid dyes at alkaline $\mathrm{pH}$ was due to the presence of the excess hydroxyl ions competing with the dye anions for the adsorption sites $^{31}$.

When summarizing the effects of the thermal and chemical modifications of the smectite clay (BC) on its sorption capacities for the RB-81 and DB-74 dyes, it was found that: 
- the amount of the adsorbed RB-81 increased in the order:

$\mathrm{BC} \mathrm{H}_{2} \mathrm{SO}_{4}\left(9860 \mathrm{mg} \cdot \mathrm{kg}^{-1}\right)>\mathrm{BC} 250\left(3766 \mathrm{mg} \cdot \mathrm{kg}^{-1}\right)$ $>\mathrm{BC}\left(2870 \mathrm{mg} \cdot \mathrm{kg}^{-1}\right)>\mathrm{BC} \mathrm{NaOH}\left(2870 \mathrm{mg} \cdot \mathrm{kg}^{-1}\right)$;

- the amount of DB-74 increased in the order:

$\mathrm{BC} \mathrm{H}_{2} \mathrm{SO}_{4}\left(15324 \mathrm{mg} \cdot \mathrm{kg}^{-1}\right)>\mathrm{BC} \mathrm{NaOH}\left(10600 \mathrm{mg} \cdot \mathrm{kg}^{-}\right.$ 1) > BC $250\left(5848 \mathrm{mg} \cdot \mathrm{kg}^{-1}\right)>\mathrm{BC}\left(4700 \mathrm{mg} \cdot \mathrm{kg}^{-1}\right)$.

The physicochemical properties of the sorbent were not the only important factor determining the amount of the bonded dyes. Aspects such as the dye structures ${ }^{31}$ (including the number of the donor groups and their susceptibility to deprotonation under alkaline conditions), the number of the acceptor groups and their location in the benzene rings ${ }^{32}$ also played a significant role.

Both studied dyes had the same number of the donor sites, i.e. the RB-81 dye: one - $\mathrm{OH}$ group and two $-\mathrm{NH}$ groups; the DB-74 dye: one -OH group and one $-\mathrm{NH}_{2}$ group with two donors (Fig. 1).

The sulfonic groups (three and four in the RB-81 DB-74 dyes, respectively), nitrogen atoms in the azo groups (one in the RB-81; three in the DB-74) and the chlorotriazo group in the RB-81 dye could also act as acceptors. The differences in the dye amounts adsorbed by the tested clays suggest that the sulfonic groups could be important in the sorption of the anionic dyes.

Moreover, the high bonding capacity of the DB-74 dye under acidic conditions can be explained with the $\mathrm{pH}$ influence on the functional groups ${ }^{\mathbf{3 3}, \mathbf{3 4}}$. At $\mathrm{pH}=3.39$, the RB-81 molecule did not change its structure, whereas the $-\mathrm{NH}_{2}$ present in the DB-74 structure underwent protonation $\left(-\mathrm{NH}_{3}{ }^{+}\right)$. As a result, more DB-74 molecules bonded with the sorbent surface (Table 2).

Under alkaline conditions $(\mathrm{pH}=10.28)$, the $-\mathrm{NH}$ and -OH groups, present in both dye structures, underwent deprotonation $\left(-\mathrm{N}^{-},-\mathrm{O}^{-}\right)$, which reduced the number of the donor sites and the capacity of the dyes to bond with the clay sorption centers. Importantly, the $-\mathrm{NH}_{2}$ (with two donor sites) present in the DB-74 dye did not undergo the reaction ${ }^{33,34}$. Thus, the dye was effectively bonded.

Table 2. Functional groups in the dye particles under acidic and alkaline conditions

\begin{tabular}{|l|c|c|c|}
\hline & $\mathrm{pH} 8.0$ & $\mathrm{pH}=3.39$ & $\mathrm{pH}=10.28$ \\
\hline & $-\mathrm{SO}_{3} \mathrm{~N}$ & $-\mathrm{SO}_{3} \mathrm{Na}$ & $-\mathrm{SO}_{3} \mathrm{Na}$ \\
& $-\mathrm{N}=\mathrm{N}$ & $-\mathrm{N}=\mathrm{N}$ & $-\mathrm{N}=\mathrm{N}$ \\
$\mathrm{RB} 81$ & $-\mathrm{Cl}$ & $-\mathrm{Cl}$ & $-\mathrm{Cl}$ \\
& $-\mathrm{NH}-$ & $-\mathrm{NH}-$ & $-\mathrm{N}^{-}$ \\
& $-\mathrm{OH}$ & $-\mathrm{OH}$ & $-\mathrm{O}^{-}$ \\
\hline \multirow{4}{*}{$\mathrm{SB} 74$} & $-\mathrm{SO}_{3}^{-}$ & $-\mathrm{SO}_{3}^{-}$ & $-\mathrm{SO}_{3}^{-}$ \\
& $-\mathrm{N}=\mathrm{N}$ & $-\mathrm{N}=\mathrm{N}$ & $-\mathrm{N}^{-}$ \\
& $-\mathrm{OH}$ & $-\mathrm{NH}^{-}$ & $-\mathrm{O}^{-}$ \\
& $-\mathrm{NH}_{2}$ & $-\mathrm{NH}_{3}{ }^{+}$ & $-\mathrm{NH}_{2}$ \\
\hline
\end{tabular}

\section{Estimating parameters in the sorption isotherm equations}

The values of the Langmuir $\left(\mathrm{q}_{\mathrm{L}}, \mathrm{K}_{\mathrm{L}}\right)$, Freundlich $\left(\mathrm{K}_{\mathrm{F}}, 1 / \mathrm{n}\right)$ and Dubinin-Radushkevich $\left(\mathrm{q}_{\mathrm{D}}, \beta\right)$ adsorption isotherms parameters, estimated with the linear and non-linear regression methods, and the values of the determination coefficients $\left(\mathrm{R}^{2}\right)$ are given in Table 3 . They allowed the creation of the sorption isotherms in the system of $\mathrm{q}=\mathrm{f}(\mathrm{Ceq})$ (Fig. 6).

The linear regression method made use of the $\mathrm{R}^{2}$ values. It was found that the RB-81 dye sorption onto natural and modified clay was best described by the Freundlich and Dubinin-Radushkevich isotherm equ- ations. The determination coefficient values ranged from 0.9260 to 0.9691 . The $1 / \mathrm{n}$ parameter value estimated from the Freundlich equation (Eq.6) was < 1, which indicated a favorable sorption process. The values of the E coefficient calculated from Eq. (11) indicated that the physiosorption played a significant role in the adsorption process due to the weak hydrogen bond. The Langmuir equation described the RB-81 dye sorption onto natural and modified clay particles to a much lesser degree. The determination coefficients were $0.5571-0.7639$. The DB-74 dye sorption onto the natural and alkali-modified clays was well described with the Freundlich and Dubinin-Radushkevich equations. This was confirmed by the $\mathrm{R}^{2}$ values (0.9152-0.9910). At the same time, these equations described the DB-74 dye sorption onto the clay modified with the sulfuric acid to a lesser extent $\left(\mathrm{R}^{2}=0.87\right)$. The $1 / \mathrm{n}$ constant values $(<1)$ indicated a favorable sorption process while the calculated $\mathrm{E}$ coefficient values $(>8$ $\mathrm{kJ} / \mathrm{mol}$ ) pointed to the ion exchange.

Moreover, the Freundlich constant $\mathrm{K}_{\mathrm{F}}$ indicated the sorption capacity of the sorbent. The values of $\mathrm{K}_{\mathrm{F}}$ are given in Table 3. For $\mathrm{BC} \mathrm{H}_{2} \mathrm{SO}_{4}$, they were $121.6 \mathrm{dm}^{3} \cdot \mathrm{kg}^{-1}$ and $558.5 \mathrm{dm}^{3} \cdot \mathrm{kg}^{-1}$ for the $\mathrm{RB}-81$ and DB-74, respectively. The results show that the acid-activated clay had a very strong adsorption capacity for anionic dyes in the solution ${ }^{31}$.

The analyses of the theoretical isotherms took into account the estimated constant values in the equations in relation to the experimental points. It was found that the dye sorption at the low initial concentration range (up to $100 \mathrm{mg} / \mathrm{dm}^{3}$ ), was best described with the Freundlich and Dubinin-Radushkevich isotherms. For the high concentration range, the Langmuir isotherm turned out to be the most proper (Fig. 6a).

When using the non-linear regression method to estimate the constant values in the sorption isotherms, it turned out that all three isotherms were well fitted for the experimental points (Fig. 6b). The Q parameter values, obtained from the Langmuir equation, which indicated the maximum clay sorption capacity for both dyes were approx. $50 \%$ higher than the values estimated with the linear regression and $60-100 \%$ higher than the experimental values. The $1 / \mathrm{n}$ parameter values, estimated from Freundlich equation, pointed to a favorable sorption process of the studied dyes onto natural and activated clays. The estimated values of the E coefficient indicated that the physical sorption was the main mechanism of the RB-81 dye bonding, whereas the DB-74 dye was bonded with the ion exchange.

The values in parentheses were obtained with the nonlinear regression method.

\section{CONCLUSIONS}

The research into the sorption of the anionic dyes (RB-81 and DB-74) onto the natural and thermally and chemically modified smectite clays showed a significant effect of the acid modification on the amount of bonded dyes. The acid-activated smectite had a strong adsorption capacity for the anionic RB-81 and DB-74 dyes in the solution.

Regardless of the clay modification type, the dye sorption occurred at the $\mathrm{pH}>\mathrm{pH}_{\mathrm{PZC}}$, which indicated 
Table 3. Parameters of sorption isotherms of RB-81 and DB-74 dyes onto smectite clays: natural (BC) and thermally (BC 250), acid $\left(\mathrm{BC} \mathrm{H}_{2} \mathrm{SO}_{4}\right)$ and alkali $(\mathrm{BC} \mathrm{NaOH})$ modified

\begin{tabular}{|c|c|c|c|c|c|c|c|c|c|c|c|c|}
\hline & \multicolumn{3}{|c|}{ Freundlich Isotherm } & \multicolumn{5}{|c|}{ Langmuir Isotherm } & \multicolumn{4}{|c|}{ Dubinin-Radushkevich Isotherm } \\
\hline Sorbent & $\begin{array}{c}\mathrm{K}_{\mathrm{F}} \\
{\left[\mathrm{dm}^{3} \cdot \mathrm{kg}^{-1}\right]}\end{array}$ & $1 / n$ & $\mathrm{R}^{2}$ & $\left.\begin{array}{c}q_{\max } \\
{\left[\mathrm{mg} \cdot \mathrm{kg}^{-1}\right]}\end{array}\right]$ & $\mid\left[\mathrm{mg}^{\mathrm{q}} \cdot \mathrm{kg}^{-1}\right]$ & $\mathrm{K}_{\mathrm{L}}$ & $\mathrm{R}_{\mathrm{L}}$ & $\mathrm{R}^{2}$ & $\begin{array}{c}\mathrm{q}_{\mathrm{D}} \\
{\left[\mathrm{mol} \cdot \mathrm{kg}^{-1}\right]}\end{array}$ & {$\left[\mathrm{mol}^{2} \cdot \mathrm{kJ}^{-2}\right]$} & $\begin{array}{c}\mathrm{E} \\
{\left[\mathrm{kJ} \cdot \mathrm{Mol}^{-1}\right]}\end{array}$ & $\mathrm{R}^{2}$ \\
\hline \multicolumn{13}{|c|}{ REACTIVE BLUE 81} \\
\hline BC & $\begin{array}{c}86.90 \\
(26.40)\end{array}$ & $\begin{array}{c}0.5140 \\
(0.7005)\end{array}$ & $\begin{array}{c}0.940 \\
(0.983)\end{array}$ & 2870 & $\begin{array}{c}3650 \\
(5878)\end{array}$ & $\begin{array}{c}0.0031 \\
(0.0011)\end{array}$ & $\begin{array}{c}0.2413 \\
(0.4606)\end{array}$ & $\begin{array}{c}0.698 \\
(0.988)\end{array}$ & $\begin{array}{c}0.0119 \\
(0.0301)\end{array}$ & $\begin{array}{c}0.0062 \\
(0.0074)\end{array}$ & $\begin{array}{c}8.8059 \\
(8.2101)\end{array}$ & $\begin{array}{c}0.930 \\
(0.986) \\
\end{array}$ \\
\hline $\mathrm{BC} 250^{\circ} \mathrm{C}$ & $\begin{array}{c}65.16 \\
(85.36)\end{array}$ & $\begin{array}{c}0.5970 \\
(0.5768)\end{array}$ & $\begin{array}{c}0.936 \\
(0.972)\end{array}$ & 3766 & $\begin{array}{c}5319 \\
(5481)\end{array}$ & $\begin{array}{c}0.0031 \\
(0.0029) \\
\end{array}$ & $\begin{array}{c}0.2366 \\
(0.2513) \\
\end{array}$ & $\begin{array}{c}0.764 \\
(0.995) \\
\end{array}$ & $\begin{array}{c}0.0316 \\
(0.0269) \\
\end{array}$ & $\begin{array}{c}0.0065 \\
(0.0059) \\
\end{array}$ & $\begin{array}{c}8.7706 \\
(8.2367) \\
\end{array}$ & $\begin{array}{c}0.940 \\
(0.983) \\
\end{array}$ \\
\hline $\mathrm{BC} \mathrm{H}_{2} \mathrm{SO}_{4}$ & $\begin{array}{c}121.6 \\
(169.3) \\
\end{array}$ & $\begin{array}{c}0.6850 \\
(0.6564)\end{array}$ & $\begin{array}{c}0.954 \\
(0.981) \\
\end{array}$ & 9860 & $\begin{array}{c}10667 \\
(16276)\end{array}$ & $\begin{array}{c}0.0028 \\
(0.0030)\end{array}$ & $\begin{array}{c}0.2577 \\
(0.2455)\end{array}$ & $\begin{array}{c}0.557 \\
(0.997) \\
\end{array}$ & $\begin{array}{c}0.1159 \\
(0.1012)\end{array}$ & $\begin{array}{c}0.0064 \\
(0.0064)\end{array}$ & $\begin{array}{c}8.839 \\
(8.8522) \\
\end{array}$ & $\begin{array}{c}0.958 \\
(0.989) \\
\end{array}$ \\
\hline $\mathrm{BC} \mathrm{NaOH}$ & $\begin{array}{c}55.97 \\
(21.28) \\
\end{array}$ & $\begin{array}{c}0.5240 \\
(0.7128) \\
\end{array}$ & $\begin{array}{c}0.926 \\
(0.995) \\
\end{array}$ & 2652 & $\begin{array}{c}3378 \\
(5782) \\
\end{array}$ & $\begin{array}{c}0.0028 \\
(0.0009)\end{array}$ & $\begin{array}{c}0.2573 \\
(0.5056)\end{array}$ & $\begin{array}{c}0.753 \\
(0.991) \\
\end{array}$ & $\begin{array}{c}0.0172 \\
(0.0273) \\
\end{array}$ & $\begin{array}{c}0.0063 \\
(0.0075) \\
\end{array}$ & $\begin{array}{c}8.9087 \\
(8.1431) \\
\end{array}$ & $\begin{array}{c}0.969 \\
(0.993) \\
\end{array}$ \\
\hline \multicolumn{13}{|c|}{ DIRECT BLUE 74} \\
\hline BC & $\begin{array}{c}75.87 \\
(58.46) \\
\end{array}$ & $\begin{array}{c}0.6096 \\
(0.6576)\end{array}$ & $\begin{array}{c}0.990 \\
(0.998)\end{array}$ & 4700 & $\begin{array}{c}5464 \\
(8357) \\
\end{array}$ & $\begin{array}{c}0.0043 \\
(0.0015)\end{array}$ & $\begin{array}{c}0.1832 \\
(0.3856) \\
\end{array}$ & $\begin{array}{c}0.827 \\
(0.994)\end{array}$ & $\begin{array}{c}0.0130 \\
(0.0363)\end{array}$ & $\begin{array}{c}0.0044 \\
(0.0066)\end{array}$ & $\begin{array}{l}10.66 \\
(8.6846)\end{array}$ & $\begin{array}{c}0.977 \\
(0.997) \\
\end{array}$ \\
\hline $\mathrm{BC} 250^{\circ} \mathrm{C}$ & $\begin{array}{c}175.7 \\
(419.2) \\
\end{array}$ & $\begin{array}{c}0.5848 \\
(0.3977) \\
\end{array}$ & $\begin{array}{c}0.915 \\
(0.997) \\
\end{array}$ & 5848 & $\begin{array}{c}5948 \\
(6210) \\
\end{array}$ & $\begin{array}{c}0.0159 \\
(0.0086)\end{array}$ & $\begin{array}{c}0.0572 \\
(0.1006) \\
\end{array}$ & $\begin{array}{c}0.968 \\
(0.962) \\
\end{array}$ & $\begin{array}{c}0.0273 \\
(0.0179) \\
\end{array}$ & $\begin{array}{c}0.0043 \\
(0.0036)\end{array}$ & $\begin{array}{c}10.780 \\
(11.760)\end{array}$ & $\begin{array}{c}0.961 \\
(0.995) \\
\end{array}$ \\
\hline $\mathrm{BC} \mathrm{H}_{2} \mathrm{SO}_{4}$ & $\begin{array}{c}558.5 \\
(396.4) \\
\end{array}$ & $\begin{array}{c}0.5875 \\
(0.6533) \\
\end{array}$ & $\begin{array}{c}0.872 \\
(0.996)\end{array}$ & 15324 & $\begin{array}{c}16129 \\
(28915) \\
\end{array}$ & $\begin{array}{c}0.0184 \\
(0.0041)\end{array}$ & $\begin{array}{c}0.0498 \\
(0.1923)\end{array}$ & $\begin{array}{c}0.812 \\
(0.990)\end{array}$ & $\begin{array}{c}0.0587 \\
(0.1711)\end{array}$ & $\begin{array}{c}0.0038 \\
(0.0059)\end{array}$ & $\begin{array}{c}11.470 \\
(9.208) \\
\end{array}$ & $\begin{array}{c}0.878 \\
(0.993) \\
\end{array}$ \\
\hline $\mathrm{BC} \mathrm{NaOH}$ & $\begin{array}{c}111.3 \\
(248.1) \\
\end{array}$ & $\begin{array}{c}0.7763 \\
(0.6120) \\
\end{array}$ & $\begin{array}{c}0.991 \\
(0.988) \\
\end{array}$ & 10600 & $\begin{array}{c}13698 \\
(16961)\end{array}$ & $\begin{array}{c}0.0058 \\
(0.0034)\end{array}$ & $\begin{array}{c}0.1426 \\
(0.2196) \\
\end{array}$ & $\begin{array}{c}0.926 \\
(0.995) \\
\end{array}$ & $\begin{array}{c}0.0687 \\
(0.0828) \\
\end{array}$ & $\begin{array}{c}0.0055 \\
(0.0057) \\
\end{array}$ & $\begin{array}{c}9.9346 \\
(9.3263) \\
\end{array}$ & $\begin{array}{c}0.992 \\
(0.993) \\
\end{array}$ \\
\hline
\end{tabular}

The values in parentheses were obtained with the nonlinear regression method.

a)
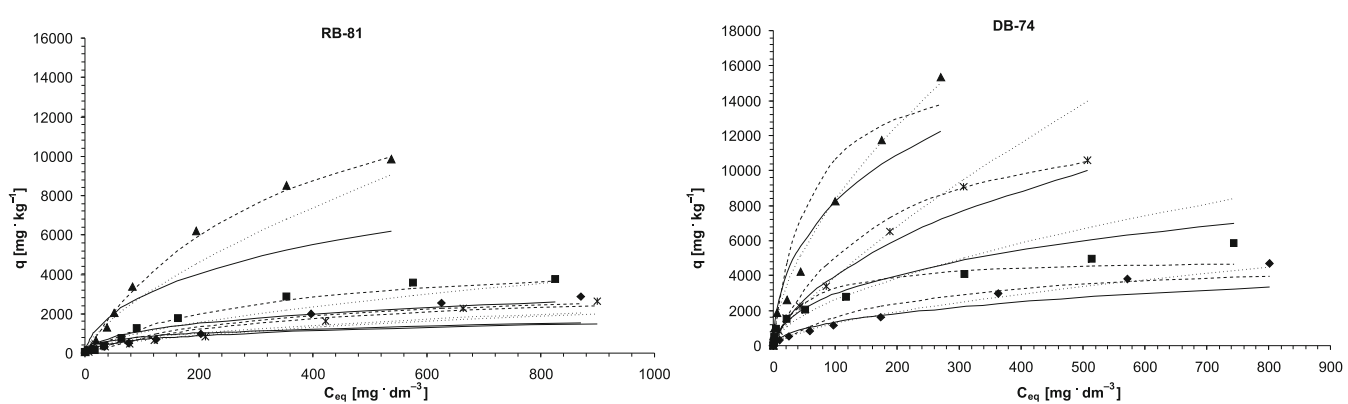

b)
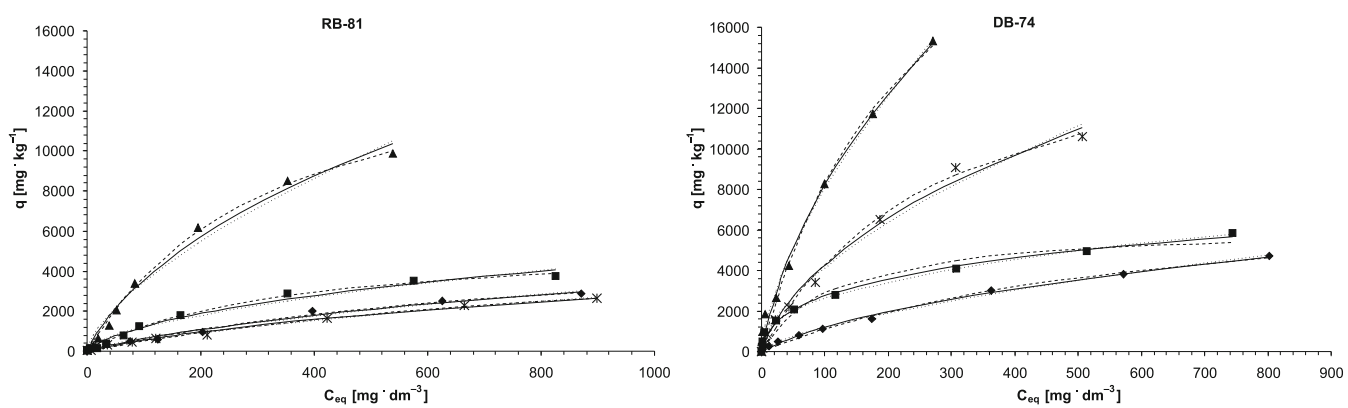

- BC

- BC 250

F Isotherm

- $\mathrm{BC} \mathrm{H} 2 \mathrm{SO} 4$

D-R Isotherm

Figure 6. Theoretical sorption isotherms of the RB- 81 and DB-74 dyes onto natural and activated smectite clays determined with the linear (a) and non-linear regression (b)

that the particles of the clay-building minerals had the negative surface charge. It was impossible to bond the dyes by means of the electrostatic interaction with the mineral surfaces. The dyes were mainly bonded with the hydrogen bonds, in which the $-\mathrm{OH},-\mathrm{NH}$ and $-\mathrm{NH}_{2}$ groups acted as the proton donors and the $-\mathrm{SiO}$ and $-\mathrm{Al}_{2} \mathrm{OH}$ groups played the role of the proton acceptors. The studied dyes could also be bound due to the interactions of the hydrated interlayer $\mathrm{Ca}^{2+}$ ions, found in the smectite clay, with the dye $-\mathrm{SO}_{3}^{-}$groups. However, this process was limited due to the dye molecule sizes. The anionic dye structures played an important role in the dye bonding, including aspects such as the number and type of the donor groups and their deprotonation capacity under alkaline conditions; and the number of the acceptor groups.

The linear regression method was used to estimate the sorption constants in the equations. It was found that the Freundlich and Dubinin-Radushkevich isotherms described the dye sorption much better than the Langmuir model. On the other hand, all three models described well the experimental data in the non-linear regression method. Furthermore, the $1 / n$ value $(<1)$ for all the dye-sorbent systems indicated the favorable sorption.

\section{ACKNOWLEDGMENT}

The study was conducted under the statute research in the Institute of Environmental Engineering of the Polish Academy of Sciences in the years 2008-2010. 


\section{LITERATURE CITED}

1. Alkan M., Doğan, M., Turhan, Y., Demirbaş, Ö. \& Turan, P. (2008). Adsorption kinetics and mechanism of maxilon blue $5 \mathrm{G}$ dye on sepiolite from aqueous solution. Chem. Eng. J. 139, 213-223. DOI:10.1016/j.cej.2007.07.080.

2. Almeida, C.A.P., Debacher, N.A., Downs, A.J., Cotte, L.T \& Mello, C.A.D. (2009). Removal of methylene blue from colored effluents by adsorption on montmorillonite clay. $J$. Colloid Interf. Sci. 332, 46-53. DOI: 10.1016/j.jcis.2008.12.012.

3. Doğan, M., Alkan, M., Demirbaş, Ö., Özdemir, Y. \& Özmetin, C. (2006). Adsorption kinetics of maxilon blue GRL onto sepiolite from aqueous solution. Chem. Eng. J. 124, 89-101. DOI: 10.1016/j.cej.2006.08.016.

4. Majewska-Nowak, K. (1986). Dye removal from industrial wastewater (in Polish). Ochr. Sr. 4, 17-22.

5. Crini, G. (2006). Non-conventional low-cost adsorbents for dye removal: A review. Bioresource Technol. 97, 1061-1085. DOI: 10.1016/j.biortech.2005.05.001.

6. Gupta, V.K. \& Suhas. (2009) Application of low-cost for dye removal - A review. J. Environ. Manage. 90, 2313-2342. DOI: 10.1016/j.jenvman.2008.11.017.

7. Shen, D., Fan, J., Zhou, W., Gao, B., Yue, Q. \& Kang, Q. (2009). Adsorption kinetics and isotherm of anionic dyes onto organo-bentonite from single and multisolute systems. $J$. Hazard. Mater. 172, 99-107. DOI: 10.1016/j.jhazmat.2009.06.139.

8. Choma, J., Jarowiec, M. \& Burakiewicz-Mortka, W. (1991). Adsorption of methylene blue from aqueous solutions on activated carbons ( in Polish). Ochr. Sr. 2, 41-44.

9. Ghadiri, S.K., Nabizadeh, R., Mahvi, A.H., Nasseri, S. Mesdaghinia, A.R. \& Talebi, S.S. (2012). Potential of granulated modified nanozeolites $\mathrm{Y}$ for MTBE removal from aqueous solutions: Kinetic and isotherm studies. Pol. J. Chem. Tech. 14(2), 1-8. DOI: 10.2478/v10026-012-0063-8.

10. Allen, S.J., Mckay, G. \& Porter, J.F. (2004). Adsorption isotherm models for basic dye adsorption by peat in single and binary component systems. J Colloid Interf Sci 280, 322-333. DOI: $10.1016 /$ j.jcis.2004.08.078.

11. Kyzioł-Komosińska, J., Rosik-Dulewska, C., Pająk, M. \& Jarzyna, M. (2010). Removal of direct dyes from wastewater by sorption onto smectite clay. Arch. Environ. Prot. 3, 3-14.

12. Namasivayam, C., Muniasamy, N., Gayatri, K., Rani, M. \& Ranganathan, K. (1996). Removal of dyes from aqueous solutions by cellulosic waste orange peel. Bioresource Technol. 57, 37-43. DOI: 10.1016/0960-8524(96)00044-2.

13. Özcan, A., Öncü, E.M. \& Özcan, A.S. (2006). Kinetics, isotherm and thermodynamic studies of adsorption of Acid Blue 193 from aqueous solutions onto natural sepiolite. Coll. Sur. A. 277, 90-97. DOI: 10.1016/j.colsurfa.2005.11.017.

14. Akl, M., Youssef, A.M., Al-Awadhi, M.M. (2013). Adsorption of acid dyes onto bentonite and surfactant-modified bentonite. J. Anal. Bioanal. Tech. 4(4) 3-7. DOI:10.4172/21559872.1000174.

15. Wang, C.C., Juang, L.C., Hsu, T.C., Lee, C.K., Lee, J.F. \& Huang, F.C. (2004). Adsorption of basic dyes onto montmorillonite. J. Colloid. Interf. Sci. 273, 80-86. DOI: 10.1016/j.jcis.2003.12.028.

16. Iyim, T.B. \& Güçlü, G. (2009). Removal of basic dyes from aqueous solutions using natural clay. Desalination 249, 1377-1379. DOI: 10.1016/j.desal.2009.06.020.

17. Turabik, M. (2008). Adsorption of basic dyes from single and binary component systems onto bentonite: Simultaneous analysis of Basic Red 46 and Basic Yellow 28 by first order derivative spectrophotometric analysis method. J. Hazard. Mater. 158, 52-64. DOI: 10.1016/j.jhazmat.2008.01.033.

18. Özcan, A., Ömeroğlu, Ç., Erdoğan, Y. \& Özcan, A.S. (2007). Modification of bentonite with a cationic surfactant: An adsorption study of textile dye Reactive Blue 19. J. Hazard. Mater. 140, 173-179. DOI: 10.1016/j.jhazmat.2006.06.138.

19. Errais, E., Duplay, J., Elhabiri, M., Khodja, M., Ocampo, R., Baltenweck-Guyot, R. \& Darragi, F. (2012). Anionic
RR120 dye adsorption onto raw clay: Surface properties and adsorption mechanism. Coll. Sur. A. 403, 69-78. DOI: 10.1016/j. colsurfa.2012.03.057.

20. Kyzioł-Komosińska, J., Pająk, M. \& Walor, K. (2009). The removal of dyes from textile wastewater using sorption method onto smectite clays (in Polish). In J. Ozonek \& M. Dudzińska (Eds.). Polska Inżynieria Środowiska. Pięć lat po wstapieniu do Unii Europejskiej (58, pp. 153-159). Monografie Komitetu Inżynierii Środowiska Polskiej Akademii Nauk.

21. Stoch, L., Bahranowski, K., Budek, L. \& Fijał, J. (1977). Bleaching properties of non-bentonitic clay materials and their modification. Mineralogia Polonica 8, 31-49.

22. Hisarli, G. (2005). The effects of acid and alkali modification on the adsorption performance of fuller's earth for basic dye. J. Colloid. Interf. Sci. 281, 18-26. DOI: 10.1016/j. jcis.2004.08.089.

23. Tamayo, A., Kyziol-Komosinska, J., Sánchez, M.J., Callejas, P., Rubio, J. \& Barba, M.F. (2012). Characterization and properties of treated smectites. J. European Ceramic. Soc. 32, 2831-2841. DOI: 10.1016/j.jeurceramsoc.2011.12.029.

24. Kyzioł-Komosińska, J. \& Pająk, M. (2012): Sorptive removal of dyes from water and wastewater using neogene smectite clays (in Polish). Work \& Studies No 83, Zabrze: Institute of Environmental Engineering of the Polish Academy of Sciences.

25. Freundlich, H.M.F. (1906). Over the adsorption in solution. Z. Phys. Chem. 57A, 385-470.

26. Langmuir, I. (1916). The constitution and fundamental properties of solids and liquids. J. Am. Chem. Soc. 38, 2221-2295. DOI: $10.1021 / \mathrm{ja} 02254 \mathrm{a} 006$.

27. Dubinin, M.M. (1960). The potential theory of adsorption of gases and vapors for adsorbents with energetically non- uniform surface. Chem. Rev. 60, 235-266. DOI: $10.1021 / \mathrm{cr} 60204 \mathrm{a} 006$.

28. Foo, K.Y. \& Hameed, B.H. (2010). Insights into the modeling of adsorption isotherm systems. Chem. Eng. J. 156, 2-10. DOI: 10.1016/j.cej.2009.09.013.

29. Brdar, M., Sciban, M., Takaci, A. \& Dosenovic, T. (2012). Comparison of two and three parameters adsorption isotherm for Cr(VI) onto Kraft lignin. Chem. Eng. J. 183, 108-111. DOI: 10.1016/j.cej.2011.12.036.

30. Ruiz, R., Blanco, C., Pesquera, C., Gonzalez, F., Benito, I. \& Lopez, J.L. (1997). Zeolitization of a bentonite and its application to the removal of ammonium ion from waste water. App. Clay Sci. 12, 73-83.

31. Ozcan, A.S. \& Ozcan, A. (2004). Adsorption of acid dyes from aqueous solutions onto acid-activated bentonite. $J$. Colloid Interf. Sci. 276, 39-46. DOI: 10.1016/j.jcis.2004.03.043.

32. Qiao, S., Hu, Q., Haghseresht, F., Hu, X. \& Lu, G.Q. (2009). An investigation on the adsorption of acid dyes on bentonite based composite adsorbent. Sep. Purif. Technol. 67, 218-225. DOI: 10.1016/j.seppur.2009.03.012.

33. Dye structure and functional groups of Direct Blue 74. Retrieved January 22, 2014, from http://www.chemicalize. org/structure $/ \# ! \mathrm{mol}=\mathrm{c} 1 \% 28 \mathrm{~S} \% 28 \% 3 \mathrm{DO} \% 29 \% 28 \% 3 \mathrm{DO}-$ $\% 29 \% 5 \mathrm{BO}-\% 5 \mathrm{D} \% 29 \mathrm{c} \% 28 \% 2 \mathrm{FN} \% 3 \mathrm{DN} \% 2 \mathrm{Fc} 2 \mathrm{c} 3 \mathrm{c} \% 28 \mathrm{c}-$ $\mathrm{c} \% 28 \mathrm{~S} \% 28 \% 3 \mathrm{DO} \% 29 \% 28 \% 3 \mathrm{DO} \% 29 \% 5 \mathrm{BO}-\% 5 \mathrm{D} \% 29 \mathrm{c}-$ c3\%29c\%28\%2FN\%3DN\%2Fc3c4c\%28cc\%28S\%28\%3DO$\% 29 \% 28 \% 3 \mathrm{DO} \% 29 \% 5 \mathrm{BO} \% 5 \mathrm{D} \% 29 \mathrm{cc} 4 \% 29 \mathrm{c} \% 28 \% 2 \mathrm{FN} \% 3 \mathrm{D}-$ $\mathrm{N} \% 2 \mathrm{Fc} 4 \mathrm{cc} \% 28 \mathrm{~S} \% 28 \% 3 \mathrm{DO} \% 29 \% 28 \% 3 \mathrm{DO} \% 29 \% 5 \mathrm{BO}-$ $\% 5 \mathrm{D} \% 29 \mathrm{ccc} 4 \% 29 \mathrm{cc} 3 \% 29 \mathrm{cc} 2 \% 29 \mathrm{c} \% 28 \mathrm{c} 2 \mathrm{c} \% 28 \mathrm{c} 1 \% 29 \mathrm{cc} \% 28 \mathrm{c}-$ c2\%29N\%290. $\% 5 \mathrm{BNa} \% 2 \mathrm{~B} \% 5 \mathrm{D} . \% 5 \mathrm{BNa} \% 2 \mathrm{~B} \% 5 \mathrm{D} . \% 5 \mathrm{BNa}-$ $\% 2 \mathrm{~B} \% 5 \mathrm{D} . \% 5 \mathrm{BNa} \% 2 \mathrm{~B} \% 5 \mathrm{D} \&$ source $=\mathrm{fp}$

34. Dye structure and functional groups of Reactive Blue 81. Retrieved January 22, 2014, from http://www.chemicalize.org/structure/\#!mol=Clc5nc\%28Nc3cc\%28cc4cc\%28c\%28\% 2FN\%3D$\mathrm{N} \% 2 \mathrm{Fc} 2 \mathrm{ccc} \% 28 \mathrm{Nc} 1 \mathrm{cccc} 1 \% 29 \mathrm{c} \% 28 \mathrm{c} 2 \% 29 \mathrm{~S} \% 28 \% 3 \mathrm{DO}-$ $\% 29 \% 28 \% 3 \mathrm{DO} \% 29 \mathrm{O} \% 5 \mathrm{BNa} \% 5 \mathrm{D} \% 29 \mathrm{c} \% 28 \mathrm{O} \% 29 \mathrm{c} 34 \% 29 \mathrm{~S} \%$ $28 \% 3 \mathrm{DO} \% 29 \% 28 \% 3 \mathrm{DO} \% 29 \mathrm{O} \% 5 \mathrm{BNa} \% 5 \mathrm{D} \% 29 \mathrm{~S} \% 28 \% 3 \mathrm{DO}-$ $\% 29 \% 28 \% 3 \mathrm{DO} \% 29 \mathrm{O} \% 5 \mathrm{BNa} \% 5 \mathrm{D} \% 29 \mathrm{nc} \% 28 \mathrm{Cl} \% 29 \mathrm{n} 5 \&$ source $=$ calculate 